\title{
Rehabilitation Medicine in Pellegrini-Stieda Syndrome with Myositis Ossificans and Neglected Patella Fracture
}

\section{Ronni Untung Handayanto, Tanti Ajoe Kesoema, Rahmi Isma AP}

Department of Physical Medicine and Rehabilitation, Faculty of Medicine Diponegoro University/Dr. Kariadi Hospital, Semarang, Indonesia

\begin{abstract}
Introduction: Pellegrini-Stieda Syndrome (PSS) is calcification of the medial collateral ligament (MCL). The manifestation are restricted motion and pain of the knee. PSS usually associated with trauma or repeated strain.

Methods: A case report of 30 year old physically active men has a severe stiffness and pain on the left knee while walking for six months. He had neglected trauma 9 years ago. There were antalgic gait, mild swelling, warm, and tenderness on medial aspect, restricted range of motion (ROM) by pain on the left knee; flexion 150. The knee X-Ray has shown the myositis ossificans and Pellegrini-Stieda lesion. Subject had undergone Rehabilitation Program, i.e. progressive gradual motion exercise and cryotherapy Results: There were reduced of pain, and increase the Left knee PROM were $15^{\circ}$ restricted of extension and $30^{\circ}$ flexion, became $8^{\circ}$ restricted of extension and $55^{\circ}$ flexion, after one month of program.
\end{abstract}

Conclusion: Pellegrini-Stieda Syndrome (PSS) is a possible complication in major knee trauma. The patient showed improvements in pain, and ROM after one month of rehabilitation programs.

Keywords: Pellegrini-Stieda Syndrome (PSS), Range-of-Motion (ROM), Medial Collateral Ligament (MCL). 


\section{ABSTRAK}

Pendahuluan: Pellegrini-Stieda Syndrome (PSS) adalah kalsifikasi ligamen medial kolateral (MCL) yang bermanifestasi berupa gerak lutut yang terbatas, disertai nyeri.

Metode: Laporan kasus pada pria 30 tahun dengan kondisi fisik yang aktif datang dengan riwayat kekakuan parah enam bulan dan nyeri pada lutut kiri terutama saat berjalan. Ditemukan pola jalan pincang, pada lutut kiri teraba hangat, dan nyeri pada aspek medial dari lutut kiri. Pada X-Ray lutut ditemukan adanya myositis ossificans dan lesi PSS. Dilakukan program rehabilitasi seperti latihan gerak gradual progresif, dan krioterapi.

Hasil: Didapatkan adanya perbaikan berupa berkurangnya nyeri dan peningkatan ROM setelah satu bulan program rehabilitasi, yaitu PROM lutut kiri sebelum program, yaitu terhambat $15^{\circ}$ ekstensi dan $30^{\circ}$ fleksi, menjadi terhambat $8^{\circ}$ ekstensi dan $55^{\circ}$ fleksi.

Kesimpulan: Pellegrini-Stieda Syndrome (PSS) adalah komplikasi yang mungkin pada trauma lutut mayor. Manajemen konservatif menggunakan program rehabilitasi menunjukkan perbaikan yang baik pada penurunan nyeri dan peningkatan ROM.

Kata kunci: Pellegrini-Stieda Syndrome (PSS), Rentang gerak (ROM), Ligamen Medial Kolateral $(M C L)$.

\section{Correspondent Detail:}

Ronni Untung Handayanto

Email : ronnikhoe.md@gmail.com

Department of Physical Medicine and

Rehabilitation, Faculty of Medicine

Diponegoro University

Dr. Kariadi Hospital,

Semarang, Indonesia

\section{INTRODUCTION}

Pellegrini in 1905 was the first to describe the sign of Pellegrini-Stieda ${ }^{1}$ and, subsequently, in 1908 Stieda reported the first series of 5

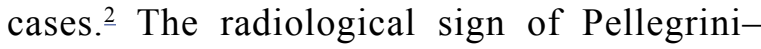
Stieda is the proximal calcification of the medial collateral ligament of the knee, after a direct or indirect trauma thereof. The radiological findings plus the clinical symptomatology of pain and restriction in the ranges of motion are known under the name of PSS. $\frac{3}{3}$ The incidence of the PSS is unknown, but the preponderance in the male gender between 25 and 40 years of age is clear, being rare in children and older people. ${ }^{4}$ Calcification may occur in the month following the trauma, and in some cases, it has exceptionally spontaneously disappeared. ${ }^{6}$ The pathophysiology of the disease is also unclear. The trigger for the PSS could be an avulsion of the medial femoral condyle or a tear of ligaments, tendons (ischiocondylar portion of the adductor magnus). In some cases, Pellegrini Stieda disease has been seen in patients without knee trauma but concomitant spinal cord injury or traumatic brain injury. ${ }^{3,4}$ 
It is postulated that soft tissue edema and the subsequent deposition of hydroxyapatite or calcium pyrophosphate is generated after a traumatic injury. The majority of patients are asymptomatic. In the clinical examination can be found pain localized in the medial aspect of the knee and limitation of the flexion-extension movements of the joint. ${ }^{7}$ Ossification could happen within 11 days to 6 weeks after post trauma. A network of the new bone formation around the periphery of the mass of the medial condyle is formed in 6 to 8 weeks. Duration of the condition is usually about 5 to 6 months. ${ }^{8,9}$

After a while, the phenomena could occur: the inflammation subsides with partial or complete resorption of the calcium salts, or the mass becomes ossified and may be connected by a pedicle to the femoral condyle. The last is called Pellegrini-Stieda syndrome. ${ }^{10}$

The treatment of the PSS is usually conservative. Treatment ranges from rest, physical therapy, use of NSAID, glucocorticoid injection, and even surgery in severe and recalcitrant cases. ${ }^{10,11}$

Measures such as rest, physical therapy, steroids, and lidocaine injections have been successfully used. When a full range of motion of the knee is attained, no any form of pain, no limitation on activities and also, the muscles, Quadriceps, and Hamstrings, have fully recovered. This means full recovery. ${ }^{10,11}$

\section{CASE PRESENTATION}

30 years old physically active man who worked as a chef, come with stiffness and pain on the left knee since six months ago, that become more severe since three months ago. The pain felt continuously and progressively, but he can walk independently. He was hit by a motorcycle since nine months ago, with swollen and bruised left knee, but he didn't go to doctor. He was treated by alternative medicine (traditional massage) for months. He didn't feel better, so he decided to go hospital and he reffered to Kariadi General Hospital for further examination and treatment.

On physical examination, he walk in antalgic gait, vital signs were normal, from the localized examination, inspection of lower extremity, there was mild edema on the left knee, with no muscle atrophy. From palpation, felt warm and pain. There was limitation in range of motion of left knee. It found there was limitation in full passive extension and flexion. In neutral position, the flexion was $15^{\circ}$, passive extension cannot be achieved and still in flexion $15^{\circ}$, passive flexion was $30^{\circ}$. Ligamentous laxity test was difficult to be examined because of pain.

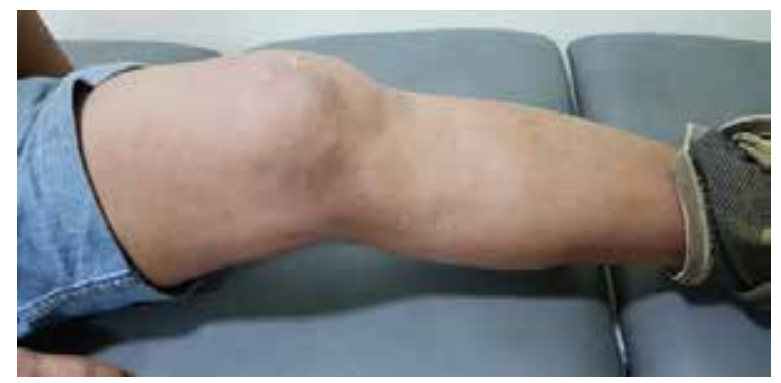

Figure 1. Left Knee Appearance 


\section{Imaging}

Knee X-ray examination showed defect on patellar bone (old pattelar fracture) and medial condyle distal femoral bone, also malunion distal femoral bone suggestive myositis ossificans. There was soft tissue opacity around it extend to the femoral bone. Furthermore, at the medial knee aspect there was calcification of the proximal aspect of the MCL suggestive for Pellegrini-Stieda lesion (PSS). There was no narrowing knee space compartment, intact knee joint alignment.

From ultrasound examination (Figure 3) showed calcification at the MCL's deep band of left knee (PSS lession).

There was no MRI examination. A diagnosis of PSS, old patellar fracture and myositis ossificans in this case was made based on the imaging and clinical findings.
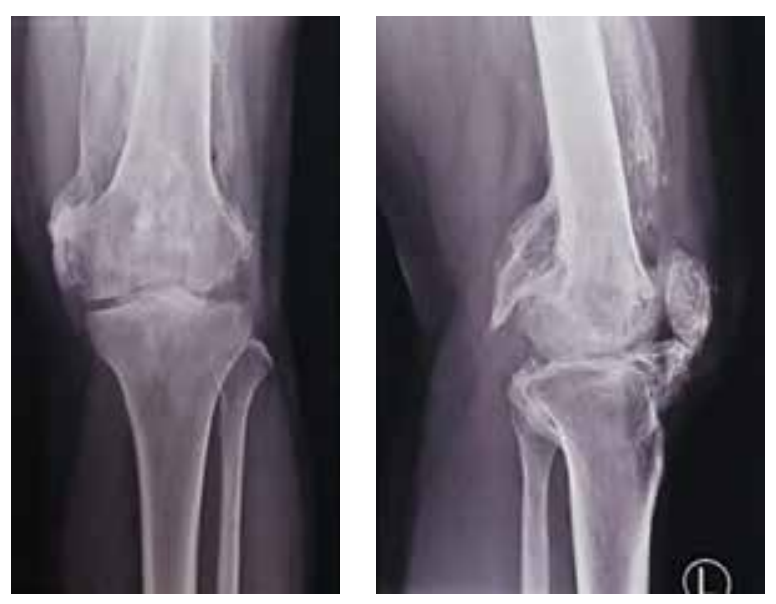

Figure 2. Old fracture of os patella and calcification over the medial collateral ligaments suggestive Pellegrini-Stieda appearance

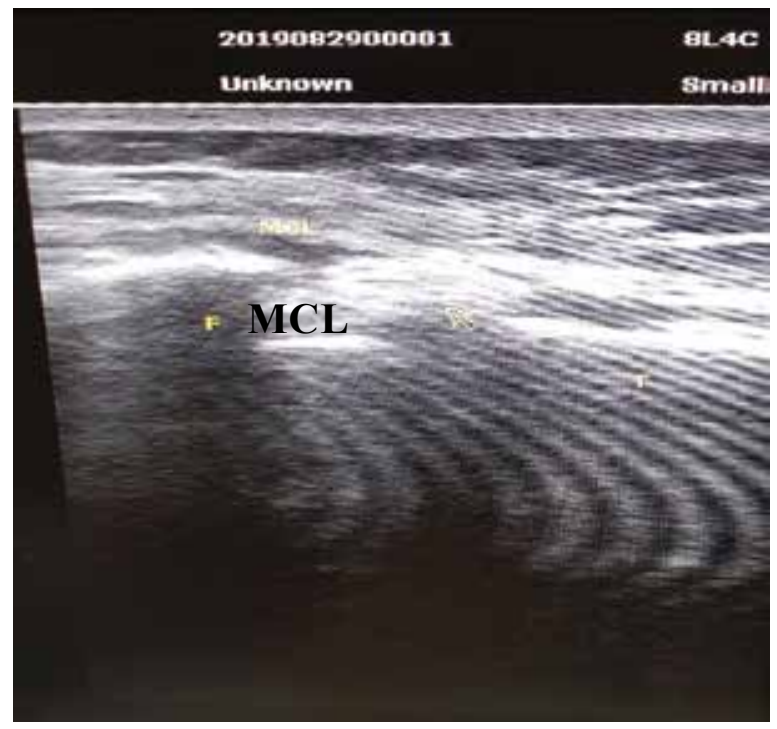

Figure 3. Ultrasound examination of MCL.

\section{Management}

In Physical Medicine and Rehabilitation Unit, the patient managed conservatively with medical rehabilitation programs, and home programs with a good result.

The medical rehabilitation programs consist of cold therapy, and passive range of motion (PROM) exercise. Cold therapy administered by cryotherapy for reducing pain and inflammation that still remained in affected knee. Meanwhile for the passive range of motion (PROM) exercise was conducted using continuous passive motion (CPM) device, this exercise aimed to achieve the functional knee motion. It was operated gradually from lesser to greater angle that still well tolerated by the patient. All the rehabilitation protocols are performed half an hour each session, repeated two times a week in hospital. The home programs consisted of range of motion exercise and ice compress that must be done at least twice daily. From the orthopedic 
department the patient has already given natrium diclofenac $50 \mathrm{mg}$ twice daily.

\section{Home Programs}

First conservative was avoiding overload and micro-trauma, therefore forced rehabilitation or early high impact activity is to be avoided. ${ }^{10}$ Ice compress is useful, it is important to apply for the knee 2-3 times per day. This should be done for 10-20 minutes at a time. The best time to do ice compress was after exercise or do a lot of walking, by knee extended in straight position with a towel rolled under the ankle. It is recommended not to sit for more than 45 minutes at any given time because the knee may become stiff. It is recommended whether sitting for a prolonged time the patient must immediately go stand and walk a short distance and attempt to bend and straighten your knee several times.

The home exercise program will assist recovery and improve strength. It consisted of motion and muscle exercises. Patient must take time to exercise every day. The exercise program will take approximately 30 minutes to complete and should be done twice per day minimally. Home exercise program should be simple, easy, and tolerable to patient.

The different steps of the functional rehabilitation can be completed, only in a more controlled and slow manner. The rehabilitation progressivity should be done in step by step procedure to avoid overload and micro trauma on the knee complex region which may prolong the recovery.

The serial exercises has done to 3 sets each moment, and 20 repetitions in one set, performed twice a day. The exercise programe were:
1. Ankle pumps:

Patient lying flat on back with knee straight, bend ankle up and down as far as possible in both directions. This exercise benefit to reduce the edema and swelling at the lower extremities.

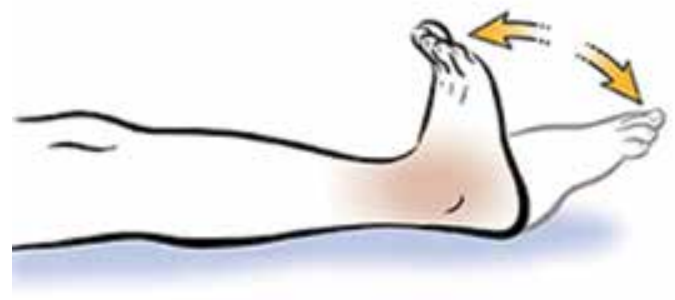

Figure 4. Ankle Pumps

2. Heel slides:

Lying flat on back with knees straight, slowly slide your heel in toward your buttocks. Patient should then straighten to the starting position. Please keep your foot on the surface at all times.

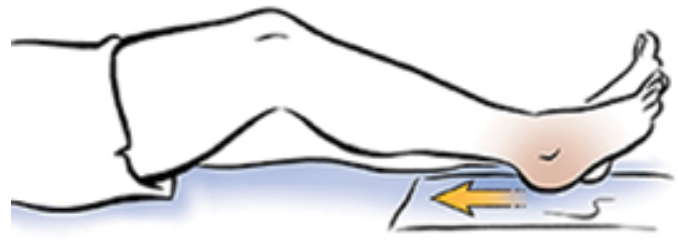

Figure 5. Heel Slides

3. Knee press:

With legs straight and a towel rolled up under the ankle, press knee down for contracting the thigh muscle. Hold for 5 seconds and then relax.

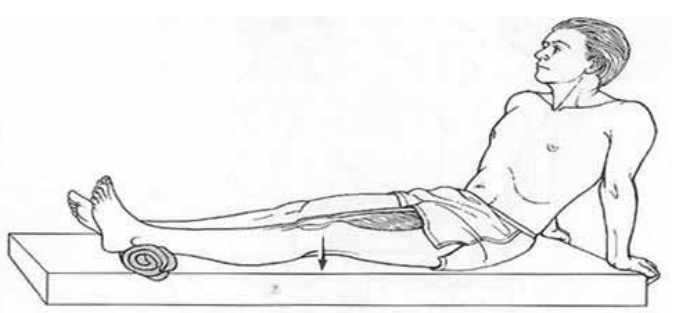

Figure 6. Knee Press 
4. Straight leg raise:

While lying flat on the back with uninvolved leg bent and your foot flat on the surface, tighten thigh and lift the involved leg. Keep the knee straight. Only lift to the height of the uninvolved knee.

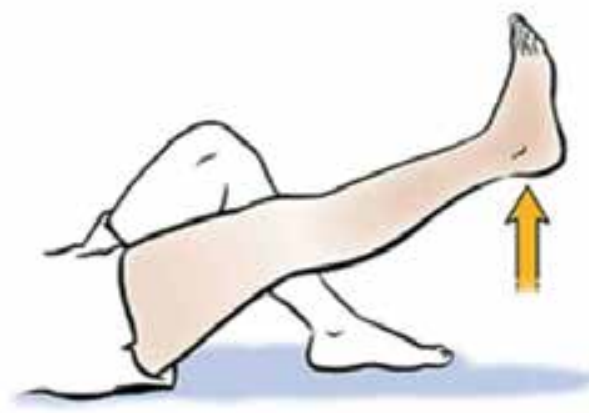

Figure 7. Straight Leg Raise

5. Standing knee bending:

While holding on to a supportive surface, on standing position, bend the involved knee so that the foot rises toward your buttock.

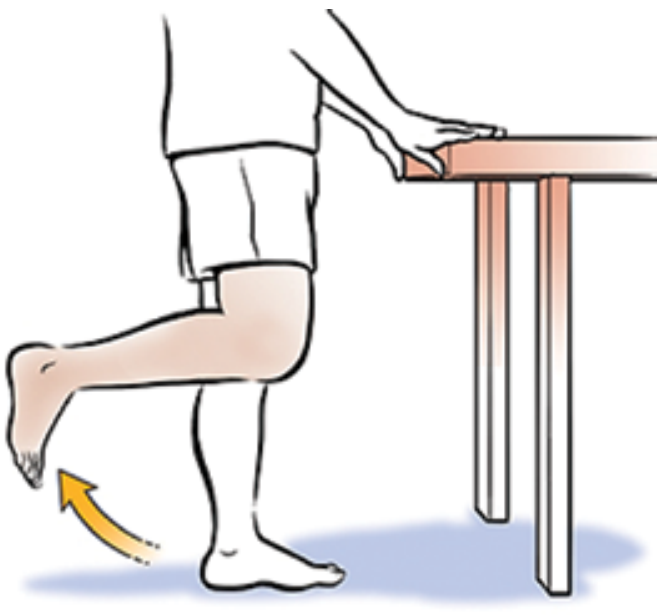

Figure 8. Standing Knee Bending

6. Heel raises:

Stand and holding on to a supportive surface, lift both heels off the ground toward the ceiling. Hold for 5 seconds and then slowly return to the starting position.

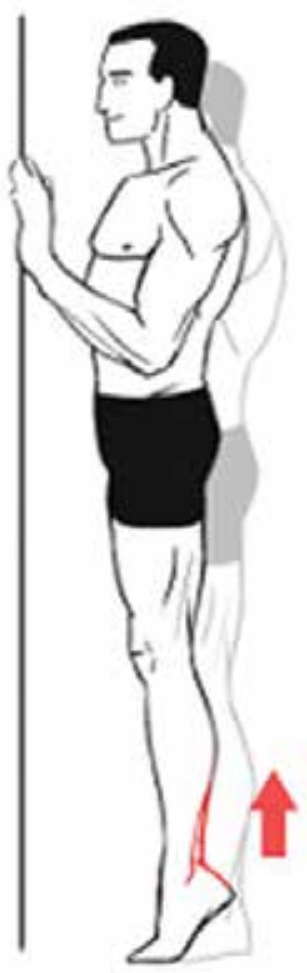

Figure 9. Heel Raises

7. Quad set:

Quadriceps activation exercise. Patient lay on the ground or table and place a rolled up towel/shirts under the knee. This will act as a lever which will make it easier to activate quadriceps muscle, then attempt to squeeze the towel.

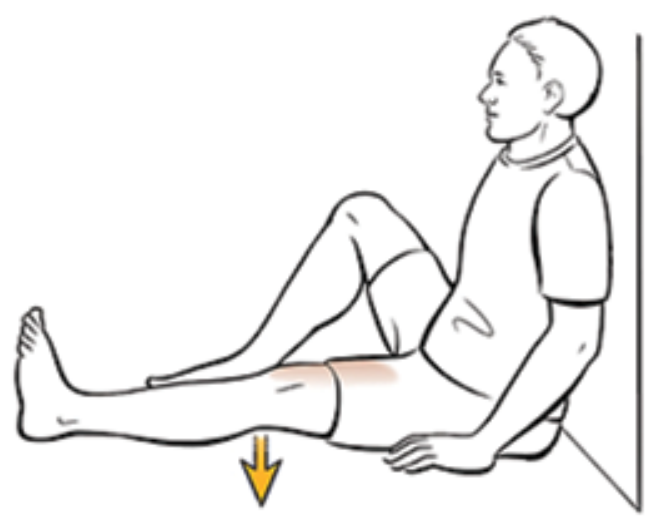

Figure 10. Quad Set 


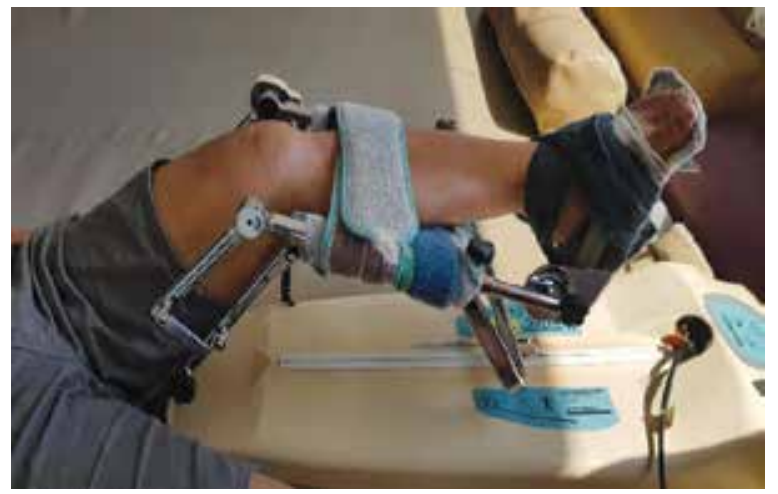

Figure 11. Rehabilitation programs using continuous passive motion.

\section{Outcome}

After underwent the rehabilitation programs the patient showed an overall improvement, especially on the range of motion (ROM) of left knee and pain reduction which helped patient to ambulate easier. After one-monthrehabilitation programs, left knee's range of motion (ROM) are improved, neutral position was measured on flexion $8^{\circ}$, PROM extension was not fully achieved and still in flexion $8^{\circ}$ position, PROM for flexion was $55^{\circ}$ flexion. Compared to one month earlier neutral position was restricted on flexion $15^{\circ}$ and $30^{\circ}$ of flexion. There was reduced of pain. Further evaluation using gait analysis devices are needed in this case. Follow up and continuing medical rehabilitation programs are needed, aimed for the better result in knee's functional motion, and walking function.

\section{DISCUSSION}

Pellegrini-Stieda Syndrome is the proximal calcification of the medial collateral ligament of the knee, after a direct or indirect trauma thereof, causing valgus stress with disruption of the MCL fibers. ${ }^{9}$ The radiological findings plus the clinical symptomatology of pain and restriction in the ranges of motion are known under the name of PSS., ${ }^{1,6}$ Diagnosis is established from anamnesis, general inspection, and measurements such as palpation, range of motion (ROM) examination, gait, radiological imaging using X-ray, and for the further details there should be MRI imaging diagnostic applied to this patient. Some of studies proven that musculoskeletal ultrasonography has also proven useful in diagnosing PellegriniStieda lesions and can often elicit associated edema, which then be performed in this patient. The presence of symptoms associated with radiological findings is known as PellegriniStieda syndrome (PSS). ${ }^{4}$ Even so sometimes still difficult to discern PSS from heterotopic ossification and myositis ossificans. From this patient clinical symptoms, physical examination and radiological imaging result, these related conditions can be diagnosed as PSS.

The objective of medical rehabilitation principles in this condition were: control edema, activation of Quadriceps muscles, restore the functional motion of the knee. $\frac{10,11}{}$

Despite of PSS, patient was also diagnosed with old patellar fracture which already resolved and myositis ossificans at the lateral part of the left knee, all of these musculoskeletal conditions may showed that the mechanism of injuries which we considered as major trauma are playing a part to developed this condition. We knew that patellar fracture mechanism in traumatic case may caused by direct blow such as fall on flexed knee which caused high axial loading on knee compartment with valgus or varus stress.., 12 
We concluded from this injury mechanisms are the causative problem to developed this condition in this case report. The rehabilitation program in this patient are consist of two major aspects, first is the hospital based medical rehabilitation, the second is home programs. Both are conservative programs which showed to be effective and improve the overall patient's condition, as for in this patient, the clinical result still can be achieved for more. Follow up and continuing the rehabilitation programs in this patient are recommended.

\section{CONCLUSION}

PSS is possible complication on major knee trauma, which these conditions mostly are managed conservatively. In this case report showed that PSS followed with myositis ossificans and old patellar fracture can be treated by intensive physical medicine and rehabilitation programs consist of motion and muscle exercise combined with cold therapy and oral medication (NSAID) with a good result. After underwent one month rehabilitation programs we reported improvement on functional motion on the left knee and pain reduction, thus may increase patient's gait function.

\section{REFERENCES}

1. Siddiq MAB, Jahan I. Medial collateral ligament calcification: a rare knee pain entity with literature review. Acta Radiol Open. 2017;6(11):2058460117738549. doi:10.1177/2058460117738549
2. Mavrogenis AF, Soucacos PN, Papagelopoulos PJ. Heterotopic ossification revisited. Orthopedics. 2011; 34(3):177.

3. Somford MP, Janssen RPA, Meijer D, Roeling TAP, Brown C Jr, Eygendaal D. The Pellegrini-Stieda Lesion of the Knee: An Anatomical and Radiological Review. J Knee Surg. 2019; 32(7):637-641.

4. Torrance DA, Degraauw C. Treatment of post-traumatic myositis ossificans of the anterior thigh with extracorporeal shock wave therapy. J Can Chiropr Assoc. 2011;55(4):240-246.

5. Kitcat M, Hunter JE, Malata CM. Sciatic neuroma presenting forty years after above-knee amputation. Open Prthop J. 2009;30:125-7.

6. Santos Sánchez JA, Ramos Pascua LR, García Casado D, Bermúdez López C. Pellegrini-Stieda syndrome as a cause of knee pain. 2012; 38(8):543-7.

7. Stock A, Ballmer PM. Symptomatic calcification of the lateral collateral knee ligament. Orthopade. 2013;42:780-2.

8. Andrews K, Lu A, Mckean L, Ebraheim N. J Orthop. Review: Medial collateral ligament injuries. 2017; 14(4):550-554.

9. Nur H, Aytekin A, Gilgil E. Medial collateral ligament bursitis in a patient with knee osteoarthritis.

10. J Back Musculoskelet Rehabil. 2018;31(4):589-591. doi: 10.3233/BMR169741 .

11. Theivendran K, Lever CJ, Hart WJ. Good result after surgical treatment 
of Pellegrini-Stieda syndrome. Knee Surg Sports Traumatol Arthrosc. 2009; 17(10):1231-3.

12. Theivendran K, Lever CJ, Hart WJ. Good result after surgical treatment of Pellegrini-Stieda syndrome. Knee Surg Sports Traumatol Arthrosc.2009; 17(10):

1231-3.
13. DeLong JM1, Waterman BR. Surgical Techniques for the Reconstruction of Medial Collateral Ligament and Posteromedial Corner Injuries of the Knee: A Systematic Review Arthroscopy. 2015;31(11):2258-72.e1. doi: 10.1016/j. arthro.2015.05.011. 